\title{
Analgesic efficacy of the association of cryotherapy and transcutaneous electrical nerve stimulation
}

\author{
Eficácia analgésica da associação da crioterapia e da estimulação elétrica nervosa transcutânea
}

Dalvania Alves da Silva1, Geísa Ferreira Gomes Peixoto², Karilane Maria Silvino Rodrigues², Vanessa Ximenes Farias²

DOI 10.5935/2595-0118.20180052

\section{ABSTRACT}

BACKGROUND AND OBJECTIVES: Cryotherapy and transcutaneous electrical nerve stimulation are physiotherapeutic resources widely used for the treatment of pain, due to their analgesic actions proved by scientific evidence. The concomitant use of these two therapeutic modalities in clinical practice is becoming more and more recurrent, justified by the assumption of boosting the analgesic effect. However, some physiotherapists disagree with this practice and believe that the simultaneous use of cryotherapy and transcutaneous electrical nerve stimulation nullifies its effects. The objective of this study was to carry out a bibliographic review of studies on the effects of the simultaneous use of cryotherapy and transcutaneous electrical nerve stimulation in pain treatments.

CONTENTS: We selected articles published between 20062018 in the databases Scielo, LILACS, Medline and Pubmed. The selection was based on the crossing of the keywords: transcutaneous electrical nerve stimulation, cryotherapy and analgesia. The final sample consisted of 6 articles.

CONCLUSION: The results of the analysis of the selected articles showed that, as already scientifically proved, the effects of cryotherapy and transcutaneous electrical nerve stimulation alone have their analgesic efficacy. However, most of the studies did not demonstrate a significant improvement in pain with the associated use of transcutaneous electrical nerve stimulation and cryotherapy compared to the isolated use of these physiotherapeutic resources, reinforcing the need for further research to elucidate the issue.

Keywords: Analgesia, Cryotherapy, Transcutaneous electrical nerve stimulation.

\section{RESUMO}

JUSTIFICATIVA E OBJETIVOS: Crioterapia e estimulação elétrica nervosa transcutânea são recursos fisioterapêuticos amplamente utilizados para o tratamento da dor, devido a suas ações analgésicas comprovadas por evidências científicas. Torna-se cada vez mais recorrente o uso concomitante dessas duas modalidades terapêuticas na prática clínica, justificando-se com o pressuposto de potencialização do efeito analgésico. No entanto, alguns fisioterapeutas discordam dessa prática e acreditam que o uso simultâneo da crioterapia com a estimulação elétrica nervosa transcutânea leva à anulação dos seus efeitos. O objetivo deste estudo foi realizar uma revisão bibliográfica de estudos sobre os efeitos do uso simultâneo da crioterapia e da estimulação elétrica nervosa transcutânea nos tratamentos para dor.

CONTEÚDO: Foram selecionados artigos publicados entre os anos 2006-2018 nas seguintes bibliotecas e bases de dados: Scielo, LILACS, Medline e Pubmed. A seleção foi baseada no cruzamento dos descritores: estimulação elétrica nervosa transcutânea, crioterapia e analgesia. A amostra final foi composta por 6 artigos.

CONCLUSÂO: O resultado da análise dos artigos selecionados mostrou que, como já comprovado cientificamente, os efeitos da crioterapia e da estimulação elétrica nervosa transcutânea isoladamente têm sua eficácia analgésica. Entretanto, a maioria dos estudos não demonstrou melhora significativa da dor com o uso associado da crioterapia com estimulaçáo elétrica nervosa transcutânea comparado ao uso isolado dos recursos fisioterapêuticos, reforçando a necessidade de mais pesquisas que elucidem a questão.

Descritores: Analgesia, Crioterapia, Estimulação elétrica nervosa transcutânea.

\section{INTRODUCTION}

Pain was defined by the International Association for the Study of Pain (IASP) as an "unpleasant sensory and emotional experience associated with actual or potential tissue damage". It is a symptom common to numerous pathological conditions, whose occurrence is increasingly more frequent due to the new life habits, the modern human's decline to endure suffering, the extension of people's lives in general, and of the patients with naturally lethal clinical conditions ${ }^{1}$.

Among the electrothermal phototherapy resources used in physiotherapy for the treatment of pain, the cryotherapy and transcutaneous electrical nerve stimulation (TENS) stand out ${ }^{2}$.

The cryotherapy is a technique that uses the cold with the purpose of absorbing heat from the body tissue in which it is being 
applied, having as consequences the decrease of the metabolism, anti-inflammatory and analgesic effects. Studies show that the analgesic action mechanism of the cryotherapy involves the reduction in the conduction velocity of the nerve fibers due to the asynchronous transmission in pain fibers, release of endorphins, and the inhibition of spinal neurons, besides an increase in the refractory period, which leads to a gradual reduction in the transmission of impulses in the sensitive nerves ${ }^{3}$.

The TENS consists of a therapeutic electrical current used as a physiotherapeutic resource inducing analgesia, introduced in the human body tissue through the skin via the electrodes ${ }^{4}$. Studies propose that the TENS promote the analgesia through the Gate Control Theory (GCT), and through the release of endogenous opioids. The GCT suggests that the TENS promotes the analgesia through the activation of afferent $A \beta$ nerve fibers, which are thick, myelinated and of fast conduction, without activating the small-diameter nociceptive fibers (A-delta and C fibers). This way, the inhibition of nociceptive neurons happens in the dorsal horn of the spinal cord due to the activity of the A-beta ${ }^{5}$ fibers. Also, studies show that the low-frequency TENS activates endogenous receptors in the spinal cord and brainstem, temporally prolonging the analgesia in a motor level ${ }^{6}$.

The TENS can be classified in four modalities: conventional, acupuncture, brief, intense, and burst. The most used methods are the conventional (high frequency and low-intensity) and acupuncture (low frequency and high-intensity). Such modalities present different pain modulation mechanisms. Studies demonstrate that the application of the conventional TENS preferably stimulates larger nerve fibers $(A \beta$, afferent peripheral nerve fibers that transmit low-intensity mechanical stimulation information), modulating the pain at the medullar level, explained by the GCT ${ }^{7,8}$. In the acupuncture-like TENS, small-peripheral nerve fibers that transmit mechanical stimulation and fast pain), modulating the pain at the supraspinatus level through the release of opioids and endogenous neuromediators, suppressing the transmission and perception of the harmful stimulations $s^{7,9}$.

Often, it can be observed in the physiotherapy clinical practice the simultaneous use of the cryotherapy and TENS with the purpose of inducing the analgesia and optimizing the analgesic effect. However, some professionals believe that the combined use of these two therapeutic modalities cancels each other effects. The purpose of this study was to perform a bibliographic review on the simultaneous use of cryotherapy and TENS in the treatments for pain since a scientific basis is required to justify this use.

\section{CONTENTS}

The development of this review was performed in stages, 1) Establishment of the guiding question; 2) Selection of the articles based on the inclusion and exclusion criteria; 3) Analysis of the selected studies; 4) Interpretation of the results.

The inclusion criteria were articles in Portuguese registered in the electronic libraries and database Scientific Electronic Library Online (Scielo, Medline, LILACS, and Pubmed). The original articles, provided in full text, published in journals classified by the Qualis as extracts A and B of the CAPES, the Brazilian Federal Agency for Support and Evaluation of Graduate Education, in the period from 2006 to February 2018, that had the following Health Sciences Descriptors (DeCS): TENS, cryotherapy, analgesia. Thesis, dissertations, books, and chapters of books were excluded from the research and those that did not correspond to the proposed theme. Bibliographic references of the selected articles were analyzed, and relevant articles were included.

After applying the preset inclusion and exclusion criteria, the sample was represented by six articles. For the ascertainment of the data, an instrument was prepared with the following variable: authors, type of study, sample, year of publication, primary results and conclusions. The analysis of the articles proceeded descriptively, and the results were presented as a table.

The research's result on the databases gathered the total of 93 articles. A total of 5 articles was found at the Scielo database, 11 at the BIREME, eight at LILACS, 55 at Pubmed, and 14 articles at Medline. After a meticulous analysis of the articles and excluding the recurrent articles or the ones that did not meet the theme to be analyzed, six articles were selected to form the review of the literature since they were consistent to the purposes of the work (Figure 1). The characterization of the articles is presented in table 1 .

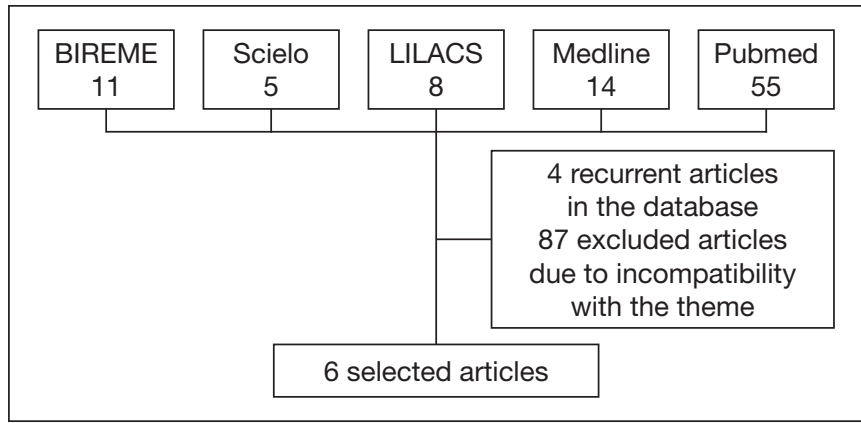

Figure 1. Flow diagram of the included and excluded studies

Table 1. Articles selected for the final sample

\begin{tabular}{|c|c|c|c|c|c|}
\hline Authors & Types of study & Purposes & Samples & Intervention Time & Conclusions \\
\hline $\begin{array}{l}\text { Maciel et } \\
\text { al. }^{10}\end{array}$ & $\begin{array}{l}\text { Cross-sectional } \\
\text { study with quasi- } \\
\text {-experimental de- } \\
\text { sign }\end{array}$ & $\begin{array}{l}\text { Evaluate the effects of } \\
\text { the isolated and com- } \\
\text { bined application of the } \\
\text { TENS and the cryothe- } \\
\text { rapy on the pressure- } \\
\text {-induced pain threshold } \\
\text { in healthy subjects. }\end{array}$ & $\begin{array}{l}40 \text { healthy volunteers, } \\
20 \text { men, and } 20 \text { women. } \\
\text { Divided into } 4 \text { groups: } \\
\text { Cryotherapy, TENS and } \\
\text { CryoTENS, and Placebo }\end{array}$ & $\begin{array}{l}\text { All subjects were } \\
\text { submitted to inter- } \\
\text { ventions, on alternate } \\
\text { days, to the three pro- } \\
\text { tocols. }\end{array}$ & $\begin{array}{l}\text { The study showed that the } \\
\text { cryotherapy, TENS, and } \\
\text { CryoTENS techniques were } \\
\text { effective in the pain threshold. } \\
\text { However, the cryotherapy } \\
\text { stood out as having the most } \\
\text { prolonged analgesic effect. }\end{array}$ \\
\hline
\end{tabular}


Table 1. Articles selected for the final sample - continuation

\begin{tabular}{|c|c|c|c|c|c|}
\hline Authors & Types of study & Purposes & Samples & Intervention Time & Conclusions \\
\hline $\begin{array}{l}\text { Abreu, } \\
\text { Santos } \\
\text { and } \\
\text { Ventura }^{11}\end{array}$ & Clinical trial & $\begin{array}{l}\text { Evaluate the analgesic } \\
\text { effectiveness of using } \\
\text { TENS and cryotherapy } \\
\text { individually and combi- } \\
\text { ned to relieve chronic } \\
\text { low back pain. }\end{array}$ & $\begin{array}{l}6 \text { patients with chronic } \\
\text { back pain. Divided into } \\
3 \text { groups: cryotherapy, } \\
\text { TENS, and TENS + cryo- } \\
\text { therapy. }\end{array}$ & $\begin{array}{l}\text { Five days of attendan- } \\
\text { ce with the analgesic } \\
\text { technique being ap- } \\
\text { plied for } 20 \text { minutes. }\end{array}$ & $\begin{array}{l}\text { The three modalities of thera- } \\
\text { py used were effective in the } \\
\text { relief of the back pain. The } \\
\text { combined therapy did not } \\
\text { have a significantly higher } \\
\text { effect than the others. }\end{array}$ \\
\hline $\begin{array}{l}\text { Ribeiro, } \\
\text { Monteiro } \\
\text { and } \\
\text { Abdon }^{12}\end{array}$ & $\begin{array}{l}\text { Prospective expe- } \\
\text { rimental study }\end{array}$ & $\begin{array}{l}\text { Verify the effect of cryo- } \\
\text { therapy and TENS si- } \\
\text { multaneously in the low } \\
\text { back pain treatment. }\end{array}$ & $\begin{array}{l}12 \text { patients of the female } \\
\text { sex and with low back } \\
\text { pain diagnosis. Divided } \\
\text { into groups as group A } \\
\text { (TENS), group B (cryo- } \\
\text { therapy) and group C } \\
\text { (CryoTENS). }\end{array}$ & $\begin{array}{l}\text { Eight attendances, on } \\
\text { two days of the week, } \\
\text { applying } 30 \text { minutes } \\
\text { of isolated or combi- } \\
\text { ned therapies follo- } \\
\text { wed by stretching. }\end{array}$ & $\begin{array}{l}\text { The results suggest that the } \\
\text { use of the TENS and cryothe- } \\
\text { rapy together did not levera- } \\
\text { ge the effects already obtai- } \\
\text { ned with the isolated applica- } \\
\text { tion of these resources. }\end{array}$ \\
\hline $\begin{array}{l}\text { Santuzzi } \\
\text { et al. }{ }^{13}\end{array}$ & Experimental trial & $\begin{array}{l}\text { Evaluate the effects of } \\
\text { the TENS and cryothe- } \\
\text { rapy, used isolated or } \\
\text { combined, on the fre- } \\
\text { quency of the action } \\
\text { potentials of the femoral } \\
\text { nerve. }\end{array}$ & $\begin{array}{l}9 \text { Wistar rats, with body } \\
\text { weight between } 300 \\
\text { and } 350 \mathrm{~g} \text {, divided into } \\
3 \text { groups: submitted to } \\
\text { TENS, cryotherapy, and } \\
\text { combined therapy appli- } \\
\text { cations. }\end{array}$ & $\begin{array}{l}\text { TENS }(50 \mathrm{~Hz}, 10 \mathrm{~m} \AA) \\
\text { for five minutes, iso- } \\
\text { lated } \\
\text { CRYO and combined } \\
\text { therapy (AT) for } 10 \mathrm{mi}- \\
\text { nutes. }\end{array}$ & $\begin{array}{l}\text { The combination of the non- } \\
\text {-invasive analgesic modali- } \\
\text { ties CRYO and TENS signi- } \\
\text { ficantly alleviates the effects } \\
\text { produced by the TENS sepa- } \\
\text { rately on the femoral nerve } \\
\text { electrical activity (FNA) of the } \\
\text { anesthetized rats. }\end{array}$ \\
\hline $\begin{array}{l}\text { Macedo } \\
\text { et al. }{ }^{15}\end{array}$ & $\begin{array}{l}\text { Randomized con- } \\
\text { trolled trial }\end{array}$ & $\begin{array}{l}\text { Evaluate the immediate } \\
\text { effect of the conven- } \\
\text { tional TENS combined } \\
\text { to cryotherapy in the } \\
\text { threshold of pain and } \\
\text { tolerance on healthy in- } \\
\text { dividuals. }\end{array}$ & $\begin{array}{l}112 \text { healthy women. The } \\
\text { volunteers were divided } \\
\text { into seven groups: control, } \\
\text { placebo TENS, conven- } \\
\text { tional TENS, burst-mode } \\
\text { TENS, cryotherapy, cryo- } \\
\text { therapy with burst-mode } \\
\text { TENS, and cryotherapy } \\
\text { with conventional TENS. }\end{array}$ & $\begin{array}{l}\text { Single-intervention for } \\
\text { data collection. }\end{array}$ & $\begin{array}{l}\text { The results suggest optimi- } \\
\text { zation of the analgesic effect } \\
\text { with the use of the burst-mo- } \\
\text { de TENS combined to cryo- } \\
\text { therapy. The same did not } \\
\text { take place when combined } \\
\text { with the conventional TENS. }\end{array}$ \\
\hline $\begin{array}{l}\text { Farias et } \\
\text { al. }^{2}\end{array}$ & $\begin{array}{l}\text { Descriptive ob- } \\
\text { servational case } \\
\text { series study }\end{array}$ & $\begin{array}{l}\text { To compare the analge- } \\
\text { sic effect of the TENS, } \\
\text { cryotherapy, and Cryo- } \\
\text { TENS on healthy people. }\end{array}$ & $\begin{array}{l}13 \text { healthy volunteers of } \\
\text { the female gender aged } \\
\text { between } 16 \text { and } 20 \text {. The } \\
\text { three analgesic techni- } \\
\text { ques were used in each } \\
\text { volunteer: TENS, cryo- } \\
\text { therapy, analgesia. }\end{array}$ & $\begin{array}{l}\text { Single intervention for } \\
\text { data collection held } \\
\text { from September to } \\
\text { October } 2007 .\end{array}$ & $\begin{array}{l}\text { The superiority of the Cryo- } \\
\text { TENS against the cryother- } \\
\text { apy and TENS was not ob- } \\
\text { served on the pain threshold, } \\
\text { and the three techniques are } \\
\text { equally effective to relieve } \\
\text { the pain in healthy people. }\end{array}$ \\
\hline
\end{tabular}

TENS: transcutaneous electrical nerve stimulation; FNA = femoral nerve electrical activity.

\section{DISCUSSION}

Farias et al. ${ }^{2}$ studied the effect of using the conventional TENS $(100 \mathrm{~Hz}$ frequency; $75 \mu$ s pulse duration, for 20 minutes), and cryotherapy, separately and combined, on the pain sensitivity of young, healthy, adult women that volunteered. The authors assessed the pain sensitivity through the use of an adipometer in the triceps skinfold and the visual analog scale (VAS) of pain as a reference to the beginning of the pain perception after the therapeutic intervention. The results showed that there was no meaningful difference in the effect of these resources used separately or combined.

Similarly, Maciel et al. ${ }^{10}$ also evaluated the effect of using the TENS and cryotherapy, separately and combined, on the pressure-induced pain threshold. However, it used a pressure algometer and the VAS as an evaluation instrument of the pressure-induced pain threshold in healthy subjects of both genders. The pain threshold was determined before, immediately after, as well as 10, 20, and 30 minutes after the application of the analgesia techniques. The results of this study showed that the cryotherapy, TENS, and CryoTENS in- creased the pressure-induced pain threshold. However, the cryotherapy separately presented a more prolonged analgesic effect.

Other studies investigated the efficacy of the cryotherapy combined with the TENS on pathological conditions like, for example, the low back pain. Abreu, Santos e Ventura ${ }^{11}$ investigated the analgesic efficacy of combining cryotherapy and TENS (CryoTENS) on chronic low back pain on women. To evaluate the pain, they used the VAS before and after applying the resources. The authors demonstrated that the use of the combined therapy did not promote substantial improvement regarding the isolated therapy modalities, although the three analgesic modalities have shown themselves effective in relieving the chronic low back pain of the patients. This study supports the Ribeiro, Monteiro and Abdon $^{12}$ results, who also evaluated the possible benefits of the combined cryotherapy and TENS use, twice a week, for one month, in women with low back pain. They used the VAS as an evaluation instrument, besides the measures of the lumbar spine range of motion through goniometry and measurement of the strength of muscles that may be compromised in case of low back pain (tibialis, quadratus lumborum, psoas, and pyramidal). The results 
of this study showed that although the use of the TENS and the combined therapy (CryoTENS) significantly improved the pain, this decrease in the group treated with the cryotherapy and TENS simultaneously was not markedly higher than in the groups that were treated with both separately. Besides, there was no substantial improvement in the range of motion, in spite of occurring pain betterment, which is a significant limiting factor.

In addition to the studies in humans, Santuzzi et al. ${ }^{13}$ evaluated the effect of using the TENS and the cryotherapy, isolated or combined, on the femoral nerve electrical activity of rats. Since the physiological analgesia mechanisms of the two therapeutic modalities are opposite; while one reduces the nerve conduction velocity, the other stimulates the nerve fibers, the purpose of the authors was to elucidate the questions related to the use of this combined therapy on the frequency of the action potentials of the femoral nerve. Their experiments showed that the association between the analgesic modalities significantly alleviates the effects produced by the TENS separately on the FNA of rats, suggesting caution in the simultaneous application of the TENS and the cryotherapy in the physiotherapeutic clinical practice. Furthermore, to Santuzzi et al. ${ }^{13}$, the therapeutic application of the cryotherapy with the TENS reduces the tactile sensitivity, with the ideal intensity of the TENS to be applied being less perceived. Andrews ${ }^{14}$ confirms that the ice may reduce the nerve conduction velocity and explains that after applying twenty minutes of cryotherapy with TENS, the nerve conduction is reduced in up to $29.4 \%$, further reinforcing the caution on the combined use of these therapeutic resources.

The randomized controlled trial by Macedo et al. ${ }^{15}$ carried out with 112 young healthy women evaluated the effect of combining the burst-mode TENS $(100 \mathrm{~Hz}$ frequency with $4 \mathrm{~Hz}$ burst frequency, $200 \mu$ s pulse duration, and high-intensity) and the conventional TENS $(100 \mathrm{~Hz}$ frequency, $100 \mu$ s pulse duration, and low-intensity) with the cryotherapy on the pressure-induced pain. The interventions were applied for 25 minutes. The pain threshold and tolerance in the lateral epicondyle region were evaluated through a pressure algometer before and after using the techniques separately and combined. The study showed that both, pain and tolerance threshold, significantly decreased in the placebo and control groups but increased in the groups that used cryotherapy, burst-mode TENS, and burst-mode TENS combined to cryotherapy. No alteration was verified on the pressure-induced pain threshold and tolerance due to the use of the conventional TENS coupled to cryotherapy. The authors suggest that the use of ice does not negatively affect the burstmode TENS analgesic action mechanism, which happens through the stimulation of the motor nerve fibers to produce muscular contraction and thus inducing the release of endogenous opioids.

The electric stimulation has been broadly used in the physiotherapy practice, differing from other electrotherapy resources due to the modulation of physical parameters such as frequency, pulse duration, type of current and waveform ${ }^{16}$. Regarding treatment for acute or chronic pain, the TENS is a low-cost non-pharmacological intervention, with no potential to toxicity, few adverse effects, easy-to-use, which can be utilized for long periods and presents immediate analgesic effect ${ }^{17}$. The easiness to handle this resource and its low-cost makes it quite marketed, and it can be used by the patient himself, which could lead to improvement of the secondary symptoms, such as sleep disorders, emotional conditions, and quality of $\operatorname{life}^{18}$. Studies showed that the TENS efficacy is related to the adjustments in the intensity, pulse width, and current frequency parameters ${ }^{17}$. In the different frequencies and intensities clinically used, the TENS activates large diameter afferent fibers ${ }^{19,20}$. The afferent impulses sent to the central nervous system (CNS) activate a descending inhibitory system to reduce hyperalgesia. This way, the TENS minimizes the hyperalgesia through peripheral and central mechanisms. The high-frequency TENS produces analgesia through the activation of endogenous inhibitory mechanisms in the CNS involving the opioid GABA, while the low-frequency TENS uses the classical inhibitory pathway activating the serotonin, in addition to the GABA. Both, all in all, activate inhibitory pathways to reduce the excitability and posterior neuronal sensitization in the dorsal horn of the spinal cord, thus reducing the pain ${ }^{17}$. Through peripheral mechanisms, the TENS may change the excitability of peripheral nociceptors reducing the impulses to the CNS.

Cryotherapy, in its turn, is also a physiotherapeutic resource widely used when planning to achieve analgesia. Among the cryotherapy physiological effects, the decrease of the cell metabolism and vasoconstriction with consequent reduction of the blood flow stand out. It is also observed the reduction of metabolic waste, reduction of the inflammation and muscle spasm ${ }^{21,22}$. The analgesia obtained through using cryotherapy is due to the effect of the reduction of the nerve conduction velocity which, in its turn, is a consequence of the decreased neuronal metabolism and the sodium-potassium $\left(\mathrm{Na}^{+} / \mathrm{K}^{+}\right)$pump activity, increasing the excitability threshold of the sensory neurons at the application site. Besides, the effects associated with the reduction of the inflammatory and edematous process also contribute to lower sensitization of the nociceptors in the tissue involved in the pathological and painful process under discussion ${ }^{23,24}$. Herrera et al. ${ }^{25}$ observed a meaningful reduction of the nerve conduction velocity of the tibial (motor) and the sural (sensorial) nerves after cryotherapy. The cryotherapy induces local effects at the spinal cord level through neurological and vascular mechanisms.

In the face of different analgesia mechanisms, there is an intense debate regarding the best possible therapeutic effect of combining the use of cryotherapy and TENS, since one resource diminishes the nerve conduction velocity and the other uses electrical stimulations to evoke sensorial impulses and induce analgesia through the gates control mechanism. This way, this method of application seems contradictory, since the physiological mechanisms contrast with each other and theoretically would cancel each other. The studies that approach this theme have shown, in their majority, that there is no optimization of the analgesic results with the combination of these two therapeutic modalities and, in parallel, do not present evidence strong enough to assure that one cancels the effect of the others. Nonetheless, studies with higher methodological reliability and physiological rationale of the displayed results are necessary so that this questioning can be genuinely ascertained.

\section{CONCLUSION}

This study's results have shown that the use of cryotherapy with the TENS is effective therapeutic practices to relieve the pain. 
However, more researches attesting to the optimization of the analgesic effects proposed by the simultaneous use of the therapies are needed. On the other hand, no negative points invalidating this therapeutic practice were observed.

\section{REFERENCES}

1. Teixeira MJ, Marcon RM, Rocha RO. Epidemiologia da dor. In: Teixeira MJ, Figueiró JAB. Dor: epidemiologia, fisiopatologia, avaliação, síndromes dolorosas e tratamento. Săo Paulo: Editorial Moreira Júnior; 2001. 1-7p.

2. Farias RS, Melo RS, Machado YF, Lima FM, Andrade PR. O uso da tens, crioterapia e criotens na resoluçáo da dor. Rev Bras Ciênc Saúde. 2010;14(1):27-36.

3. Nadler SF, Weingand K, Kruse RJ. The physiologic basis and clinical applications of cryotherapy and thermotherapy for the pain practitioner. Pain Physician. 2004;7(3):395-9.

4. Sluka KA, Walsh D. Transcutaneous electrical nerve stimulation: basic science mechanisms and clinical effectiveness. J Pain. 2003;4(3):109-21.

5. Melzack R, Wall PD. Pain mechanisms: a new theory. Science. 1965;150(699):971-8.

6. DeSantana JM, Walsh DM, Vance C, Rakel BA, Sluka KA. Effectiveness of transcutaneous electrical nerve stimulation for treatment of hyperalgesia and pain. Curr Rheumatol Rep. 2008;10(6):492-9.

7. Santos PC, Ramos JL, Motta MA, Montenegro EJ. Efeitos da TENS acupuntural no limiar da dor induzida pelo frio. Fisioter Mov. 2008;21(4):43-9.

8. Cameron M. Agentes Físicos na Reabilitaçấo. Rio de Janeiro: Elsevier; 2009.

9. Raimundo AK, Souza LA, Silveira RF, Cerqueira MC, Rodrigues J, Dini PD. Dosagem de serotonina sistêmica após aplicação da eletroestimulaçáo nervosa transcutânea (TENS). Fisioter Mov. 2009;2(3):365-74.

10. Maciel LF, Ferreira JJ, Santos HH, Andrade PR. Efeitos da estimulação elétrica nervosa transcutânea e da crioterapia sobre o limiar de dor induzida por pressão. Fisioter Pesq. 2014;21(3):249-56.

11. Abreu, EA, Santos JD, Ventura PL. Eficácia analgésica da associaçấo da eletroestimulação nervosa transcutânea e crioterapia na lombalgia crônica. Rev Dor. 2011;12(1):23-8.
12. Ribeiro RS, Monteiro TV, Abdon AP. Estudo do efeito da utilização simultânea da crioterapia e da TENS nos pacientes portadores de lombalgia. Rev Ter Man. 2006;4(16):82-7.

13. Santuzzi CH, Gonçalves WL, Rocha SS, Castro ME, Gouvea SA, Abreu GR. Efeitos da crioterapia, estimulação elétrica transcutânea e da sua associação na atividade elétrica do nervo femoral em ratos. Rev Bras Fisioter. 2008;12(6):441-6.

14. Andrews HW. Reabilitaçáo Física das lesôes desportivas. $3^{a}$ ed. Rio de Janeiro: Guanabara Koogan; 2000.

15. Macedo LB, Josué AM, Maia PH, Câmara AE, Brasileiro JS. Effect of burst TENS and conventional TENS combined with cryotherapy on pressure pain threshold: randomised, controlled, clinical trial. Physiotherapy. 2015;101(2):155-60.

16. Ferreira FC, Issy AM, Sakata RK. [Assessing the effects of transcutaneous electrical nerve stimulation (TENS) in post-thoracotomy analgesia]. Rev Bras Anestesiol. 2011;61(5):561-7. English, Portuguese, Spanish.

17. Vance CG, Dailey DL, Rakel BA, Sluka KA. Using TENS for pain control: the state of the evidence. Pain Manag. 2014;4(3):197-209.

18. Silva TF, Suda EY, Marçulo CA, Paes FH, Pinheiro GT. Comparaçăo dos efeitos da estimulaçấo elétrica nervosa transcutânea e da hidroterapia na dor, flexibilidade e qualidade de vida de pacientes com fibromialgia. Fisioter Pesqui. 2008;15(2):118-24.

19. Levin MF, Hui-Chan CW. Conventional and acupuncture-like transcutaneous electrical nerve stimulation excite similar afferent fibers. Arch Phys Med Rehabil. 1993;74(1):54-60.

20. Radhakrishnan R, Sluka KA. Deep tissue afferents, but not cutaneous afferents, mediate transcutaneous electrical nerve stimulation-induced antihyperalgesia. J Pain. 2005;6(10):673-80.

21. Starkey, C. Recursos terapêuticos em fisioterapia. $4^{\text {th }}$ ed. Barueri: Manole; 2017.

22. Freitas C, Luzardo R. Crioterapia: efeitos sobre as lesôes musculares. Rev Epist Transversalis. 2013;4(1):1-7.

23. Branco PS, Martelo D, Constantino H, Lopes M, José R, Tomás R, et al. Temas de reabilitação - agentes físicos. Porto, Portugal; 2005. 11-20p.

24. Macedo CS, Guirro RR. Crioterapia: teoria e prática baseada em evidência. Profisio esportiva e traumato-ortópedica, Porto Alegre; 2013; 1: 65-95p.

25. Herrera E, Sandoval MC, Camargo DM, Salvini TF. Motor and sensory nerve conduction are affected differently by ice pack, ice massage, and cold-water immersion. Phys Ther. 2010;90(4):581-91. 